\title{
Peroxidase as a metric of stress tolerance and invasive potential of alligator weed (Alternanthera philoxeroides) growing in aquatic habitats
}

\author{
Anindita Chatterjee* and Anjana Dewanji \\ Agricultural and Ecological Research Unit, Biological Sciences Division, Indian Statistical Institute, Kolkata - 700108, India \\ E-mail: anindita.chatterjee.ac@gmail.com(AC),anjana@isical.ac.in (AD) \\ *Corresponding author
}

Received: 14 June 2012 / Accepted: 16 November 2012 / Published online: 15 December 2012

Handling editor: Vadim Panov, REABIC, Finland

\begin{abstract}
An attempt was made to understand the potential of Alternanthera philoxeroides, alligator weed to adapt to diverse conditions present in pond ecosystems, through a correlative investigation of its natural growth pattern and peroxidase level. Eleven ponds were graded into two subjective categories: “A. philoxeroides Infestation" (High, Medium, Low) and "Level of Pollution" (High and Low), to test for difference in mean peroxidase concentration in A. philoxeroides populations. Significant changes in mean peroxidase concentration in A. philoxeroides were found in ponds categorized on the basis of level of pollution, indicating the adaptability of this plant to propagate under pollution stress. On the other hand, there was no significant change in mean peroxidase concentration for plants growing in ponds categorized on the basis of infestation showed that dense, vegetative proliferation caused no stress in A. philoxeroides. An efficient method of assaying peroxidase in $A$. philoxeroides, under field conditions, using the best suited leaf group (Tips, Tips + 1st leaf pair", 2nd leaf pair) was also explored. "Tips + 1st leaf pair" proved to be a better sample than mature leaves for estimation of peroxidase concentration in A. philoxeroides.
\end{abstract}

Key words: Alternanthera philoxeroides; peroxidase; stress; plant invasion, adaptation

\section{Introduction}

Biological invasions by non-native species are one of the worst ecological components of global environmental change. Once established, aquatic invasive plant species can have dramatic effects on the native ecosystem (Homans and Smith 2011). Alternanthera philoxeroides (Martius) Griseb (Amaranthaceae), alligator weed, an invasive perennial wetland herb originating from South America (Maddox 1968), has many attributes of a successful invasive weed such as rapid growth and vegetative propagation (Tao et al. 2009; Wang et al. 2009) as well as a broad ecological amplitude (Geng et al. 2007). This amphibious clonal plant has invaded many ecosystems worldwide (Julien et al. 1995), including riparian zones (Pan et al. 2006) and agricultural lands (Spencer and Coulson 1976), and is regarded as one of the worst weeds of the world (http://www.waikatoregion.nz).
The presence of $A$. philoxeroides in India was first reported by Maheshwari (1965) mostly in lakes and Cook (1996) reported it in ponds. There are scanty reports of this plant during the twentieth century but there seems to be a flood of reports from all over India since the last decade, reviewed by Chatterjee and Dewanji (2010). These reports show that $A$. philoxeroides has spread across climatologically diverse regions of India, like the Himalayan foothills (Negi and Hajra 2007) and mountainous states of Jammu and Kashmir (Masoodi and Khan 2012), wet rain-fed regions of North-East India (Jain et al. 2007; Singh et al. 2010), fertile Eastern Plains (Paria and Mukherjee 1981), drier plains of Central India (Singh and Pandey 1998), Western India (Wagh et al. 1995), tropical Southern India (Reddy et al. 2008) and even in coastal regions like Andaman Islands (Reddy and Raju 2005), thus indicating its ability to proliferate under diverse phytogeographical regions. The presence 
of large areas of inland aquatic bodies and wetlands in India (Prasad et al. 2004) serves as a potential habitat for the invasive A. philoxeroides (Chatterjee and Dewanji 2010). Once established, A. philoxeroides is extremely hard to control and eradication is very expensive (Jia et al. 2009; Sainty et al. 1997), thereby creating an urgent need to understand the present status of invasion in this region. Invasive plants posses certain characteristics which make them more competent to adapt and propagate in newer environments/ habitats and understanding these mechanisms is crucial for managing invasive plant species (Mack et al. 2000).

The adaptation of $A$. philoxeroides to these diverse environmental conditions might be due to its inherent potential of combating stress by upregulation of the defence mechanism of the plant. A multitude of abiotic stresses such as drought, salinity, extreme temperature and chemical toxicity pose serious threats to plants and cause rapid and excessive accumulation of reactive oxygen species, leading to oxidative stress. Peroxidase is one of the most responsive enzymes to environmental stresses as its activity has been associated with a wide range of physiological processes and can be readily monitored in crude extracts of plant tissue that readily support spectrophotometric and electrophoretic investigations (Quesada et al. 1992).

Considerable efforts have been directed towards the establishment of using enhanced peroxidise activity in plants under a variety of stresses, such as salinity (Rout and Shaw 2001), drought (Gao et al. 2008) and herbicides (Sprecher et al. 1993). Changes in peroxidase enzyme activity and its association with environmental stress in both aquatic (Hanfeng et al. 2010; Nayak et al. 2010) and terrestrial plants (Markkola et al. 1990; Fekete et al. 2002; Aki et al. 2009) have also been reported. But most studies on peroxidase enzyme assays in A.philoxeroides have been done either with plants (Ding et al. 2007; Gao et al. 2008; Santra et al. 2003; $\mathrm{Xu}$ et al. 2011a) or with callus (Xu et al. 2011b) or cell cultures (Balagtas-Burrow et al. 1993) under lab-controlled conditions. While lab bioassays may be useful as initial screening mechanisms by establishing direct physiological responses to different stressors, Schindler (1987) stressed the need for more comprehensive studies, in natural systems, for estimating the effects of stressors which could eventually form the basis of management procedures, if and when required.
This study was, therefore, undertaken to establish stress levels in A. philoxeroides under field conditions. We hypothesise that changes in peroxidase concentration, which has been associated with environmental stress, can be used to relate stress-adaptation and indicate the invasive potential of Alternanthera philoxeroides, in pond ecosystems. The following were the two objectives of this study:

(1) To undertake a baseline study of peroxidase concentration in $A$. philoxeroides growing along the littoral zone in different ponds and try to correlate peroxidase levels with stress tolerance of $A$. philoxeroides in terms of its strand-density (quantified through degree of "A. philoxeroides infestation") and eutrophic stress (categorized through "Level of Pollution") of the ponds.

(2) To assay the comparative enzyme extraction efficiency of peroxidase concentration amongst three sets of leaf sample groups of A. philoxeroides, since quite often it is not always feasible to get adequate amount of fresh young leaves for enzyme quantification.

\section{Materials and methods}

\section{Sampling sites}

Samples of $A$. philoxeroides and water were collected from eleven ponds located in Baranagar, Kolkata, India. The geographical location of ponds, local names, sizes, major associated flora, and gradation on the basis of extent of $A$. philoxeroides infestation and level of pollution based on water quality are given in Table $1 \mathrm{~A}$.

The ponds were selected such that they had varying levels of $A$. philoxeroides infestation in them. To categorize infestation, percentage cover of $A$. philoxeroides in each pond was recorded by floating a $1 \mathrm{~m}^{2}$ quadrat and based on estimated A. philoxeroides cover percent in the ponds, three categories of "A. philoxeroides infestation" were chosen, namely "High" (>75\%) under which there were 5 ponds, "Medium" $(20 \%$ $75 \%)$ which had 4 ponds and "Low" $(<20 \%)$ with only 2 ponds (Table 1A). Infestation levels from Low to High can also be visualized from Figure 1 where six of the eleven study ponds are shown e.g., Pond 1 (Figure 1 A), a relatively clean-pond with limited access while at the other extreme was Pond 10 (Figure $1 \mathrm{E}$ ), a highly polluted pond located in the vicinity of some factories with maximum influx of factorywastes. 

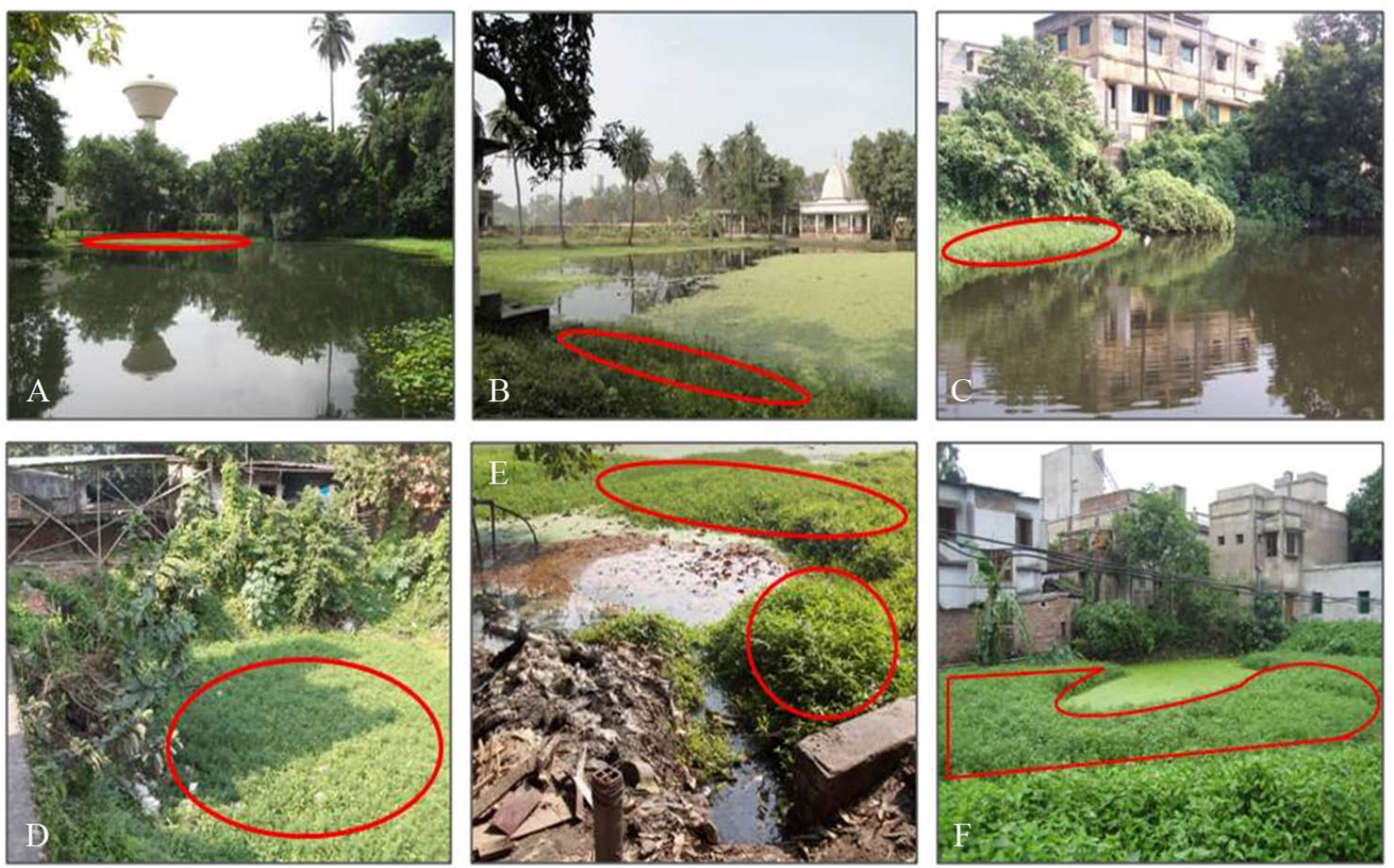

Figure 1. Six of the study ponds showing different degrees of Alternanthera philoxeroides infestation and pollution influx. A: Pond 1 (Amrapali), B: Pond 2 (Dakshineswar), C: Pond 3 (Bidyatan Sarani), D: Pond 8 (Kancher Mandir - 1), E: Pond 10 (Belghoria), F: Pond 11 (Tantipara). Red outlined areas in the photographs show regions of $A$. philoxeroides infestation (Photographs by Anindita Chatterjee).

\section{Water quality estimation}

Water samples from the ponds were analyzed for some important water quality parameters to get an idea about the pollution level present in these ponds. Using a hand-held probe (Model HQ40d, HACH Company, USA), in situ measurements of conductivity (Hach Method 8160) (Standard method 2510-B) and $\mathrm{pH}$ (Hach Method $8156 \mathrm{pH}$ Meter/Electrode Electrode Method) (USEPA method 150.1) were made. Dissolved Oxygen was measured using Portable Luminescent Dissolved Oxygen (LDO) meter (Model HQ30d, probe LDO 101, HACH Company, USA) (Hach Method 10360 D) (USEPA 40 CFR 136). Water samples were brought to the laboratory where turbidity was assessed using a turbidimeter (Model 2100P, HACH Company, USA) (EPA method 180.1), total Phosphorus was determined by the ascorbic acid method (APHA, 1998) and COD (chemical oxygen demand) was measured by photometric determination of chromate consumption by the organic compounds, after digestion in concentrated sulphuric acid solution at $148^{\circ} \mathrm{C}$ for $2 \mathrm{~h}$ by means of COD Cell Test by Merck Spectroquant (EPA method 410.4).

Each water quality parameter tested was classified into two groups denoting "Level of Pollution" on the basis of high and low values as reported in Table 1B. Final cut offs for the two categories of ponds, namely "High" and "Low", were based on standard criteria for surface water quality as per Central Pollution Control Board, India (http://www.cpcb.nic.in) and Environmental Protection Agency, U.S.A. (http://www.epa.gov) guidelines for the three basic parameters - $\mathrm{pH}$, DO and COD. Out of the eleven ponds studied, 5 ponds could be classified under the "High" category while 6 ponds could be put under the "Low" category as can be seen from Table 1 . Additionally, it was observed that the "High" ponds had an external influx of industrial and/or domestic pollutants into them while the "Low" ponds were generally located within protected premises and were subjected to limited public access/use. 
Table 1A. Descriptives of the ponds selected for the study.

\begin{tabular}{|c|c|c|c|c|c|c|}
\hline S1. No. & Pond Name & $\begin{array}{l}\text { Latitude } \\
\text { Longitude }\end{array}$ & $\begin{array}{l}\text { Size of } \\
\text { Pond } *\end{array}$ & Major Associated Flora & $\begin{array}{l}\text { A. philoxeroides } \\
\text { Infestation ** }\end{array}$ & $\begin{array}{l}\text { Level of } \\
\text { Pollution }\end{array}$ \\
\hline 1 & AMRAPALI & $\begin{array}{l}22^{\circ} 38^{\prime} 47.21^{\prime \prime} \mathrm{N} \\
88^{\circ} 22^{\prime} 37.08^{\prime \prime} \mathrm{E}\end{array}$ & Medium & Vallisneria spiralis & Low & Low \\
\hline 2 & $\begin{array}{c}\text { DAKHINESW } \\
\text { AR }\end{array}$ & $\begin{array}{l}22^{\circ} 39^{\prime} 20.57^{\prime \prime} \mathrm{N} \\
88^{\circ} 22^{\prime} 15.59^{\prime \prime} \mathrm{E}\end{array}$ & Large & $\begin{array}{l}\text { Pistia stratiotes } \\
\text { Spirodela polyrrhiza }\end{array}$ & Medium & Low \\
\hline 3 & $\begin{array}{l}\text { BIDYATAN } \\
\text { SARANI }\end{array}$ & $\begin{array}{c}22^{\circ} 38^{\prime} 58.67 " \mathrm{~N} \\
88^{\circ} 22^{\prime} 3.53^{\prime \prime} \mathrm{E}\end{array}$ & Medium & - & Medium & Low \\
\hline 4 & $\begin{array}{l}\text { BENGAL } \\
\text { IMMUNITY } \\
\text { CLUB }\end{array}$ & $\begin{array}{l}22^{\circ} 37^{\prime} 56.43^{\prime \prime N} \\
88^{\circ} 22^{\prime} 31.67^{\prime \prime} \mathrm{E}\end{array}$ & Medium & $\begin{array}{l}\text { Lemna aequinoctialis } \\
\text { Spirodela polyrrhiza }\end{array}$ & Medium & Low \\
\hline 5 & $\begin{array}{l}\text { DN 9/1 BUS } \\
\text { STAND }\end{array}$ & $\begin{array}{l}22^{\circ} 39^{\prime} 5.23^{\prime \prime N} \\
88^{\circ} 21^{\prime} 47.13^{\prime \prime} \mathrm{E}\end{array}$ & Large & $\begin{array}{l}\text { Eichhornia crassipes } \\
\text { Lemna aequinoctialis } \\
\text { Spirodela polyrrhiza }\end{array}$ & Medium & High \\
\hline 6 & $\begin{array}{l}\text { BARANAGAR } \\
\text { BAZAR }\end{array}$ & $\begin{array}{l}22^{\circ} 37^{\prime} 58.69^{\prime \prime} \mathrm{N} \\
88^{\circ} 22^{\prime} 13.63^{\prime \prime} \mathrm{E}\end{array}$ & Large & $\begin{array}{l}\text { Lemna aequinoctialis } \\
\text { Spirodela polyrrhiza }\end{array}$ & High & Low \\
\hline 7 & $\begin{array}{l}\text { PRAKASH } \\
\text { KAUR }\end{array}$ & $\begin{array}{l}22^{\circ} 40^{\prime} 2.63^{\prime \prime N} \\
88^{\circ} 22^{\prime} 30.43^{\prime \prime} \mathrm{E}\end{array}$ & Small & $\begin{array}{l}\text { Ipomoea aquatica } \\
\text { Lemna aequinoctialis }\end{array}$ & Low & Low \\
\hline 8 & $\begin{array}{l}\text { KANCHER } \\
\text { MANDIR-1 }\end{array}$ & $\begin{array}{l}22^{\circ} 38^{\prime} 22.34^{\prime \prime} \mathrm{N} \\
88^{\circ} 21^{\prime} 45.75^{\prime \prime} \mathrm{E}\end{array}$ & Small & $\begin{array}{l}\text { Lemna aequinoctialis } \\
\text { Spirodela polyrrhiza }\end{array}$ & High & High \\
\hline 9 & $\begin{array}{l}\text { KANCHER } \\
\text { MANDIR-2 }\end{array}$ & $\begin{array}{l}22^{\circ} 38^{\prime} 22.41^{\prime \prime} \mathrm{N} \\
88^{\circ} 21^{\prime} 46.76^{\prime \prime} \mathrm{E}\end{array}$ & Small & $\begin{array}{l}\text { Eichhornia crassipes } \\
\text { Lemna aequinoctialis } \\
\text { Spirodela polyrrhiza } \\
\text { Mikania scandens }\end{array}$ & High & High \\
\hline 10 & BELGHORIA & $\begin{array}{l}22^{\circ} 39^{\prime} 34.41^{\prime \prime} \mathrm{N} \\
88^{\circ} 22^{\prime} 45.88^{\prime \prime} \mathrm{E}\end{array}$ & Medium & $\begin{array}{l}\text { Eichhornia crassipes } \\
\text { Ipomoea aquatica } \\
\text { Lemna aequinoctialis }\end{array}$ & High & High \\
\hline 11 & TANTIPARA & $\begin{array}{c}22^{\circ} 38^{\prime} 33.10^{\prime \prime} \mathrm{N} \\
88^{\circ} 22^{\prime} 0.51^{\prime \prime} \mathrm{E}\end{array}$ & Small & $\begin{array}{l}\text { Spirodela polyrrhiza } \\
\text { Mikania micrantha } \\
\text { Colocasia esculenta }\end{array}$ & High & High \\
\hline
\end{tabular}

*Large: (2000 - 5000 sq. m); Medium: (1000 - 2000 sq.m); Small: (500 - 1000 sq.m)

${ }^{* *}$ High: ( $>75 \%$ Cover $)$; Medium: $(20 \%-75 \%$ Cover $)$; Low: $(<20 \%$ cover $)$

\# Low and High Level of Pollution based on criteria given in Table 1B

Table 1B. Categorisation of the study ponds on the basis of "Level of Pollution":

\begin{tabular}{ccccccc}
\hline $\begin{array}{c}\text { Level of } \\
\text { Pollution }\end{array}$ & $\mathrm{pH}$ & $\begin{array}{c}\text { Conductivity } \\
(\mu \mathrm{S} / \mathrm{cm})\end{array}$ & Turbidity $(\mathrm{NTU})$ & $\begin{array}{c}\text { Dissolved } \\
\text { Oxygen }(\mathrm{mg} / \mathrm{L})\end{array}$ & $\begin{array}{c}\text { Total Phosphorus } \\
(\mathrm{mg} / \mathrm{L})\end{array}$ & $\begin{array}{c}\text { Chemical Oxygen } \\
\text { Demand }(\mathrm{mg} / \mathrm{L})\end{array}$ \\
\hline Low & $6.5-7.5$ & $<1000$ & $<10$ & $>6.0$ & $<5$ & $<5$ \\
High & $<6.5$ & $>1000$ & $>25$ & $<3.5$ & $>5$ & $>50$ \\
\hline
\end{tabular}

\section{Plant sampling for peroxidise estimation}

Sampling was conducted in two phases, between the months of September to October in 2010 and December 2010 to January 2011 since the plant are reported to grow luxuriantly during the post monsoon (Sept-Oct) and winter (Nov-Jan) months in this region (Mukhopadhyay and Dewanji 2004). Littoral rooted and floatingmatted A.philoxeroides were sampled, as per availability, between 9:00 a.m to 12:00 noon.
It was not always be possible to sample 200$400 \mathrm{mg}$ of fresh leaf tips/buds, required for enzyme quantification, due to low population size at sites/ the minute size of leaf-tips (leaf buds) $(0.3-0.8 \mathrm{~cm}) /$ herbivory and/or insect attacks. It was, therefore, thought appropriate to collect samples from the following three leaf groups in order to determine which among the three leaf groups was best suited for enzyme extraction:

i. The young minute apical tips (leaf buds) (designated as T) $(0.3-0.8 \mathrm{~cm})$ 
ii. The apical tips (leaf buds) plus the next young leaf-pair (designated as A) $(0.8-1.5 \mathrm{~cm})$ iii. The second nodal leaf-pair (designated as $\mathrm{B})(1.5-2.0 \mathrm{~cm})$

The first two sets ( $T$ and A) comprised of 41 harvests each, considered as replicates, from eleven ponds. Simultaneously, as an additional set of experiment, the $2^{\text {nd }}$ nodal leaves of 35 samples (B), each considered as replicates, selected from 10 ponds, were harvested.

After harvesting, each set of leaf-samples were immediately packed in aluminium foil, labelled and stored in ice for transport to the laboratory. Once in the laboratory, they were immediately stored in at $-20^{\circ} \mathrm{C}$ temperature in a freezer. The samples were analysed for estimation of peroxidase concentration on the same day of sampling.

\section{Enzyme extraction and quantification}

Peroxidase was quantified according to Shannon et al. (1966) with some minor modifications. In the laboratory, a $200 \mathrm{mg}$ fresh leaf sample was taken and macerated in $1.5 \mathrm{ml} 0.9 \% \mathrm{KCl}$ under ice-cold conditions. The homogenate was centrifuged at $12,000 \mathrm{rpm}$ at $-2^{\circ} \mathrm{C}$ for 15 minutes (Remi Centrifuge, Model no. C-24). The supernatants were analysed for enzyme activity. The reaction mixture contained $2.5 \mathrm{ml}$ Acetate Buffer, $0.1 \mathrm{ml} \mathrm{3 \%} \mathrm{H}_{2} \mathrm{O}_{2}$ (substrate), $0.1 \mathrm{ml} \mathrm{o-}$ Dianisidine dihydrochloride (Sigma-Aldrich, D3252-25G) (dye) and $0.1 \mathrm{ml}$ prepared enzyme sample. After incubating for $30 \mathrm{~min}$ at room temperature, the reaction was stopped using $5 \mathrm{~N}$ $\mathrm{H}_{2} \mathrm{SO}_{4}$. A standard curve of Horse-Radish Peroxidase (HRP) (Sigma, P6782-5MG) enzyme was prepared by using different aliquots $(20,40$, $60,80,100 \mu \mathrm{g} / \mathrm{ml}$ ) of the stock HRP enzyme $(1 \mathrm{mg} / \mathrm{ml})$ and subjecting it to the same treatments. The sample absorbance was read at $460 \mathrm{~nm}$ against a blank in the spectrophotometer (Thermo Electron Corporation Helios $\gamma$ ). The peroxidase enzyme concentrations of all groups $\{(\mathrm{T}),(\mathrm{A})$ and $(\mathrm{B})\}$, were calculated and the concentration was reported as $\mu \mathrm{g} / \mathrm{gm}$ fresh weight of leaf (henceforth written as $\mu \mathrm{g} / \mathrm{gm}$ F.W.).

\section{Statistical analysis}

Exploratory data analysis was done and the descriptive statistics were obtained for the three leaf groups and the different ponds studied. Since the observations from the three leaf groups from a particular pond are likely to be dependent, hence, in order to compare any two of them, a paired sample t-test was considered appropriate based on paired observations from the eleven ponds, assumptions of normality and homogeneity of variance were checked with Kolmogorov-Smirnov's and Levene's tests, respectively. For this purpose, since there were varying number of observations from the different ponds, two observations from each pond for each type of leaf group were randomly selected to carry out the paired analysis based on their means. This ensured homogeneity of variance of the observed mean differences over the eleven ponds. Whenever, there were more than two observations (i.e., in case of Pond No's 1,10 and 11), two observations were chosen randomly for the analysis. Out of are nearly 13,000 such possible combinations for testing multiple random pairs, 100 such random combinations was rechecked to verify the results of the analysis. ANOVA (using SPSS 16.0) was performed for the three leaf groups to check for difference between ponds graded as per their extent of infestation as well as for ponds graded as per their level of pollution. As in the case of paired t-test, the means of the two randomly selected observations for each pond were also used for ANOVA to ensure homoscedascity.

\section{Results}

\section{Associated flora}

From Table 1, it can be seen that only Pond 3 was devoid of any other macrophyte growth while the presence of submerged vegetation (Vallisneria spiralis) was noted in only one pond (Pond 1). Duckweeds (Lemna/Spirodela spp.) were the most common floating species observed in nine of the eleven ponds. Pistia stratiotes (Pond 2), Ipomoea aquatica (Ponds 7 and 11), Colocasia esculenta (Pond 10) and Mikenia micrantha (Ponds 9 and 10) were the other associated species observed.

\section{Peroxide concentration}

The mean as well as the maximum and minimum peroxide concentration $(\mu \mathrm{g} / \mathrm{gm} \mathrm{FW})$ of the three leaf groups $\{(\mathrm{T}),(\mathrm{A})$ and $(\mathrm{B})\}$ in the eleven ponds in Baranagar, Kolkata is reported in Table 2. A high degree of variation in the range values (maximum and minimum) for peroxidase concentration can be seen between groups in 
individual ponds. The lowest value of the range for mean peroxidase concentrations was found for Group $\mathrm{T}$ in Pond $7(6.71 \mu \mathrm{g} / \mathrm{gm} \mathrm{FW})$, for Group A in Pond $2(6.72 \mu \mathrm{g} / \mathrm{gm} \mathrm{F.W.})$ and for Group B in Pond $3(1.31 \mu \mathrm{g} / \mathrm{gm} \mathrm{F}$.W.). On the other hand, Pond 10 (incidentally the most polluted due to influx of factory wastes (Figure 1)) showed a consistently large variation $(>270$ $\mu \mathrm{g} / \mathrm{gm} \mathrm{FW}$ ) for all groups. High mean peroxidase values $(>500 \mu \mathrm{g} / \mathrm{gm} \mathrm{FW})$ was also noted in all the leaf groups in the same pond (Pond 10).

Exploratory data analysis of peroxidase enzyme concentration $(\mu \mathrm{g} / \mathrm{gm} \mathrm{FW})$ for each of the three leaf groups based on individual observations from all ponds was also done to get an idea about the nature of the data and the resulting box-plots can be seen in Figure 2. The results show that median values for peroxidase concentration of leaf group B were lower than that of groups $\mathrm{A}$ and $\mathrm{T}$. The mean values also listed in the figure show the same trend. The variability of the peroxide concentrations in the three groups of leaf samples seems to be similar.

The results of the three possible comparisons of the leaf groups through paired t-test are given in Table 3. While there is strong significant evidence of higher means for mean peroxidase concentrations in both A $(p<0.000)$ and $T$ $(p<0.000)$ samples compared to that of group $B$, the means of $A$ and $T$ groups were not statistically different $(\mathrm{p}=0.284)$.

Of the 100 such random combinations that were also considered for multiple testing for the paired t-test analysis, although there was a slight different in $p$ values but the qualitative inference remained the same namely, in all cases the null hypotheses was rejected which is similar to the results reported for the given random combination presented in Table 3. This conforms to the findings in the box plots (Figure 2) and bar diagram (Figure 3) which shows the mean peroxidase concentrations for each leaf group based on two randomly selected observations from each of the eleven ponds. The figure distinctly shows evidence in favour of some pond-to-pond variation in mean peroxidase levels. Ponds 5, 8, 10, and 11 show higher mean peroxidase values compared to others and there are some ponds (Ponds 1, 2, 6 and 7) which show lower values. This difference suggests the existence of other factors that might be responsible for this pond-to-pond variation. Thus, ponds were divided into two categories (namely "A. philoxeroides infestation" and "Level of Pollution") as mentioned in Table 1 and ANOVA was done to test equality of means in different categories for a particular leaf group (e.g., A, T and B) based on the observed means for peroxidase concentration (of randomly selected two observations) ensuring homoscedasticity. The results are reported in Table 4.

From the table it is evident that there is no significant difference in the peroxidase concentration for each leaf group (T, A and B) on the basis of $A$. philoxeroides infestation categories of the study ponds. However, significant differences were observed for the same when the ponds were categorized on the basis of influx of pollution, with $\mathrm{T}$ having the highest significance value $(\mathrm{p}=0.005)$ amongst the three leaf groups (Table 4). Although there is a significant difference in mean peroxidase concentration between the two "level of pollution" categories (Low and High), a paired sample t-test was again carried out to check for differences within each of the two categories and results are reported in Table 5. No significant difference between the leaf-groups $\mathrm{T}$ and $\mathrm{A}$ can be seen which confirms with the results of the paired t-test reported earlier (Table 3).

\section{Discussions}

\section{Enzyme extraction efficiency amongst leaf groups of $\underline{\text { A.philoxeroides }}$}

Different plant parts have been reported to contain different concentrations of cellular stress enzyme and such variations in antioxidant potentials and peroxidase concentration have been observed in root, stem, leaf, flowers and pods in two varieties of Catharanthus roseus (Jaleel et al. 2008). Most studies use young plant parts like apical shoots or young leaves (Roy et al. 1992; Cakmak and Marschner 1992) or seedlings (Verma and Dubey 2003) for enzyme quantification although there are reports on the use of roots also in laboratory controlled experiments (Santra et al. 2003, Gao et al. 2008). However, young, apical leaves were used for enzyme quantification in this study under the assumption that they contain higher amounts of active enzyme molecules and lesser amounts of other interfering compounds. Moreover, under field conditions, collection of leaves is more convenient compared to roots, which may get destroyed during removal thus hampering enzyme extraction. Zou et al. (2012) also reported that leaves of aquatic $A$. philoxeroides had higher peroxidase than stem or roots. Three 
Figure 2. Box-Plot showing the peroxidase concentrations in three leaf groups of $A$. philoxeroides (across all the eleven study ponds pooled together).
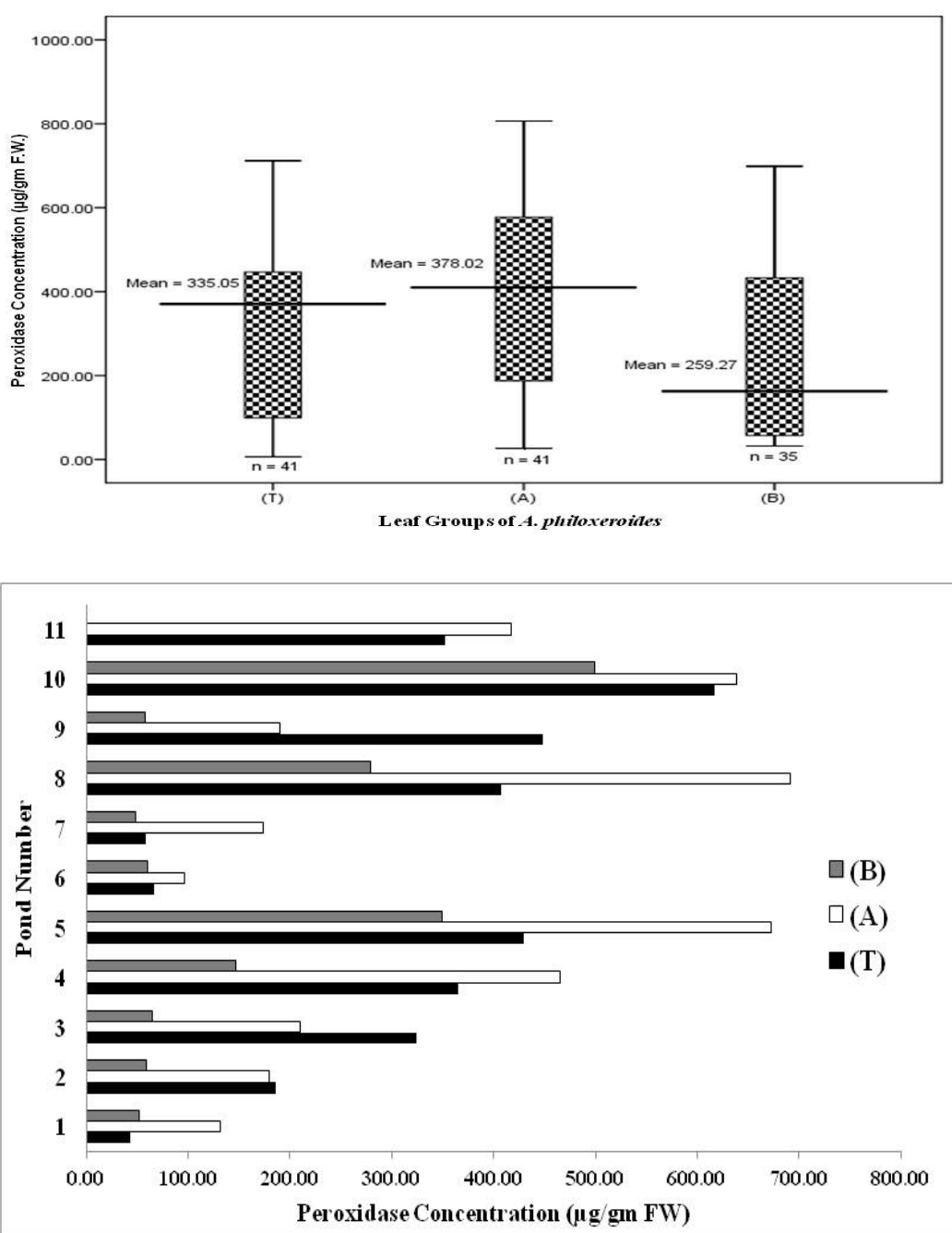

Figure 3. Comparison of peroxidase concentration values for leaf-groups (T, A and $\mathrm{B}$ ) for 11 ponds (taking randomly selected 2-datapoints for each pond). leaf groups were tested for determination of the best suited leaf group for enzyme quantification.

Amongst the three leaf groups of A.philoxeroides, as is evident from Figure 2, the highest mean peroxidase concentration was found in leaf group A $(378.02 \mu \mathrm{g} / \mathrm{gm} \mathrm{F}$.W.) followed by leaf group T $(335.05 \mu \mathrm{g} / \mathrm{gm} \mathrm{F}$.W.) and leaf group B $(259.27 \mu \mathrm{g} / \mathrm{gm} \quad$ F.W.). Paired-sample t-test between leaf groups showed significant difference in the mean peroxidase values of leaf group B with both A and $\mathrm{T}(\mathrm{p}<0.010)$ (Table 3$)$. Relatively older leaves, in Leaf group B, containing a lesser quantity of peroxidase could probably account for this difference. As enzyme molecules are highly temperature sensitive, degradation of enzymes fractions are possible during field sampling and transport (Malik and
Singh 1980). Due to their very small size $(0.3-$ $0.8 \mathrm{~cm}$ ), the younger tips (leaf group $\mathrm{T}$ ) of the plants are more likely to be subjected to heatmediated enzyme degradation during harvesting. Thus, when the next leaf pair of comparatively bigger size $(0.8-1.5 \mathrm{~cm})$ are also included with the tips (leaf group A), collection of the required amount of samples for the enzyme assay (Shannon et al. 1966) can be much faster, thereby, reducing the chance of heat-mediated enzyme degradation.

Differences in mean peroxidase concentration between leaf group A and $\mathrm{T}$ in some ponds (e.g., Ponds 3 and 9 had greater peroxidase values for group $\mathrm{T}$ as compared to that of group $\mathrm{A}$ ) were evident from Figure 3. However, no significant difference $(p=0.282)$ in the mean peroxidase 
Table 2. Pond-wise Mean Peroxidase Concentration ( $\mu \mathrm{g} / \mathrm{gm}$ F.W. $)$ of the three test groups $\left(\right.$ Tips $=\mathrm{T}$; Tips $\& 1^{\text {st }}$ Leaf $\left.=\mathrm{A}\right)$ and the $2^{\text {nd }}$ Nodal Leaf (B):

\begin{tabular}{|c|c|c|c|c|c|c|c|c|c|c|c|c|}
\hline \multirow{2}{*}{$\begin{array}{l}\dot{0} \\
z \\
\overrightarrow{0} \\
0\end{array}$} & \multirow{2}{*}{$\mathrm{N}$} & \multicolumn{3}{|c|}{$\begin{array}{c}\text { Tips (T) } \\
\text { ( } \mu \mathrm{g} / \mathrm{gm} \text { F.W.) }\end{array}$} & \multirow{2}{*}{$\mathrm{N}$} & \multicolumn{3}{|c|}{ Tips \& Leaf (A) ( $\mu \mathrm{g} / \mathrm{gm}$ F.W.) } & \multicolumn{4}{|c|}{$\begin{array}{c}2^{\text {nd }} \text { Nodal Leaf (B) } \\
(\mu \mathrm{g} / \mathrm{gm} \text { F.W. })\end{array}$} \\
\hline & & $\begin{array}{l}\text { Mean } \\
\pm \text { S.E. }\end{array}$ & Min & Max & & $\begin{array}{l}\text { Mean } \\
\pm \text { S.E. }\end{array}$ & Min & Max & $\mathrm{N}$ & $\begin{array}{l}\text { Mean } \\
\pm \text { S.E. }\end{array}$ & Min & Max \\
\hline 1 & 9 & $\begin{array}{c}84.41 \\
\pm 16.92\end{array}$ & 6.49 & 162.95 & 9 & $\begin{array}{c}120.24 \\
\pm 34.10\end{array}$ & 26.42 & 289.00 & 6 & $\begin{array}{l}45.81 \\
\pm 5.90\end{array}$ & 32.18 & 71.00 \\
\hline 2 & 2 & $\begin{array}{r}185.80 \\
\pm 17.56\end{array}$ & 168.24 & 203.36 & 2 & $\begin{array}{r}180.16 \\
\pm 11.61\end{array}$ & 168.55 & 191.76 & 2 & $\begin{array}{c}58.93 \\
\pm 1.53\end{array}$ & 57.40 & 60.46 \\
\hline 3 & 2 & $\begin{array}{l}324.59 \\
\pm 18.36\end{array}$ & 306.23 & 342.95 & 2 & $\begin{array}{l}210.17 \\
\pm 8.86\end{array}$ & 201.31 & 219.02 & 2 & $\begin{array}{c}64.92 \\
\pm 0.66\end{array}$ & 64.26 & 65.57 \\
\hline 4 & 2 & $\begin{array}{l}365.57 \\
\pm 15.41\end{array}$ & 350.16 & 380.98 & 2 & $\begin{array}{c}464.92 \\
\pm 112.13\end{array}$ & 352.79 & 577.05 & 2 & $\begin{array}{c}147.22 \\
\pm 17.37\end{array}$ & 129.84 & 164.59 \\
\hline 5 & 2 & $\begin{array}{l}429.18 \\
\pm 17.38\end{array}$ & 411.80 & 446.56 & 2 & $\begin{array}{c}673.12 \\
\pm 12.14\end{array}$ & 660.98 & 685.25 & 2 & $\begin{array}{l}349.19 \\
\pm 6.89\end{array}$ & 342.30 & 356.07 \\
\hline 6 & 2 & $\begin{array}{l}66.41 \\
\pm 4.12\end{array}$ & 62.29 & 70.53 & 2 & $\begin{array}{r}196.19 \\
\pm 27.03\end{array}$ & 169.16 & 223.21 & 2 & $\begin{array}{l}60.61 \\
\pm 5.95\end{array}$ & 54.66 & 66.56 \\
\hline 7 & 2 & $\begin{array}{c}58.02 \\
\pm 3.36\end{array}$ & 54.66 & 61.37 & 2 & $\begin{array}{c}173.28 \\
\pm 102.75\end{array}$ & 70.53 & 276.03 & 2 & $\begin{array}{l}48.71 \\
\pm 4.74\end{array}$ & 43.97 & 53.44 \\
\hline 8 & 2 & $\begin{array}{l}407.54 \\
\pm 37.05\end{array}$ & 370.49 & 444.59 & 2 & $\begin{array}{c}691.81 \\
\pm 114.76\end{array}$ & 577.05 & 806.56 & 2 & $\begin{array}{c}278.69 \\
\pm 116.07\end{array}$ & 162.62 & 394.75 \\
\hline 9 & 2 & $\begin{array}{c}447.94 \\
\pm 61.38\end{array}$ & 386.56 & 509.31 & 2 & $\begin{array}{l}190.23 \\
\pm 3.36\end{array}$ & 186.87 & 193.59 & 2 & $\begin{array}{l}58.17 \\
\pm 1.38\end{array}$ & 56.79 & 59.54 \\
\hline 10 & 3 & $\begin{array}{l}358.52 \\
\pm 6.84\end{array}$ & 348.44 & 371.56 & 3 & $\begin{array}{l}421.04 \\
\pm 5.83\end{array}$ & 409.78 & 429.33 & - & - & & \\
\hline 11 & 13 & $\begin{array}{l}563.97 \\
\pm 28.90\end{array}$ & 432.89 & 712.00 & 13 & $\begin{array}{l}584.90 \\
\pm 29.63 \\
\end{array}$ & 434.67 & 733.33 & 13 & $\begin{array}{l}512.82 \\
\pm 30.84\end{array}$ & 375.11 & 698.67 \\
\hline
\end{tabular}

Table 3. Paired-Sample t-test (taking the 2-pairs of data for each pond, selected randomly).

\begin{tabular}{|c|c|c|c|c|c|c|c|}
\hline \multirow{2}{*}{$\begin{array}{l}\text { Differences } \\
\text { between Leaf } \\
\text { Groups }\end{array}$} & \multirow[t]{2}{*}{$\mathrm{N}$} & \multirow{2}{*}{$\begin{array}{l}\text { Leaf } \\
\text { Groups }\end{array}$} & \multirow[t]{2}{*}{ Mean \pm S.E. } & \multirow{2}{*}{$\begin{array}{l}\text { Paired-Sample } \\
\text { Correlation }\end{array}$} & \multirow{2}{*}{$\begin{array}{l}\text { Paired-Sample } \\
\text { Sig. }\end{array}$} & \multicolumn{2}{|c|}{$\begin{array}{l}\text { t-test for Equality of } \\
\text { Means }\end{array}$} \\
\hline & & & & & & t-value & p-value \\
\hline$(\mathrm{A})-(\mathrm{T})$ & 11 & $\begin{array}{l}\mathrm{A} \\
\mathrm{T}\end{array}$ & $\begin{array}{l}351.922 \pm 70.07 \\
187.362 \pm 56.49\end{array}$ & 0.763 & 0.006 & 1.136 & 0.284 \\
\hline$(\mathrm{T})-(\mathrm{B})$ & 10 & $\begin{array}{l}\mathrm{T} \\
\mathrm{B}\end{array}$ & $\begin{array}{l}294.50 \pm 62.12 \\
161.71 \pm 50.40\end{array}$ & 0.767 & 0.010 & 3.322 & $<0.000$ \\
\hline (A) - (B) & 10 & $\begin{array}{l}\mathrm{A} \\
\mathrm{B}\end{array}$ & $\begin{array}{l}345.01 \pm 77.09 \\
161.71 \pm 50.40\end{array}$ & 0.897 & $<0.000$ & 4.708 & $<0.000$ \\
\hline
\end{tabular}

concentration of leaf groups $\mathrm{A}$ and $\mathrm{T}$ was found across the study ponds (Table 3 ). A comparison of peroxidase level of leaf-groups $\mathrm{T}$ and $\mathrm{A}$ of A. philoxeroides within pollution categories Low and High (Table 5) also showed no significant difference between the leaf-groups. This indicates the suitability of both $\mathrm{A}$ and $\mathrm{T}$ for estimating the peroxidase concentration in A. philoxeroides, $\mathrm{T}$ when sufficient plant tips are available at the site, otherwise opting for A.

Thus, allowing more effective and consistent sampling of young leaves of plants and minimizing the practical problem of unavailability of sufficient quantity of fresh young plant material required for the enzyme assay.

\section{Environmental stress and peroxidase variation}

Changes in levels of peroxidase were studied in natural populations of $A$. philoxeroides, in an attempt to throw some light on its ability for stress-adaptation under differing infestation as well as pollution levels.

\section{Stress due to "A. philoxeroides infestation"}

Intraspecific competition is reported to be a dominant factor for some invasive species (Blank 2010; Mangla et al. 2011). However, intraspecific competition probably does not create any stress for $A$. philoxeroides, since being a clonal plant, it is well suited to grow in 
Table 4. ANOVA of Peroxidase Conc. ( $\mu \mathrm{g} / \mathrm{gm}$ F.W.) for each of the three sample groups across ponds graded into groups according to (a) A. philoxeroides (A. ph.) Infestation (1=low, 2=medium, 3=high) and (b) Influx of Pollution (1=low and 2=high) grades:

\begin{tabular}{|c|c|c|c|c|c|}
\hline \multirow{2}{*}{$\begin{array}{l}\text { Leaf Sample } \\
\text { Group }\end{array}$} & \multirow{2}{*}{$\begin{array}{l}\text { A. ph. Infestation } \\
\text { Grade } \\
\end{array}$} & $\mathrm{N}$ & Peroxidase Concentration ( $\mu \mathrm{g} / \mathrm{gm}$ F.W.) & \multirow[t]{2}{*}{$\mathrm{F}$} & \multirow[t]{2}{*}{ p-value } \\
\hline & & & Mean \pm S.E. & & \\
\hline \multirow[t]{3}{*}{$\mathrm{T}$} & 1 & 2 & $50.56 \pm 7.46$ & \multirow{3}{*}{3.303} & \multirow{3}{*}{0.090} \\
\hline & 2 & 4 & $326.29 \pm 51.53$ & & \\
\hline & 3 & 5 & $379.46 \pm 89.52$ & & \\
\hline \multirow[t]{3}{*}{ A } & 1 & 2 & $152.44 \pm 20.85$ & \multirow{3}{*}{0.895} & \multirow{3}{*}{0.446} \\
\hline & 2 & 4 & $382.09 \pm 116.15$ & & \\
\hline & 3 & 5 & $407.58 \pm 118.02$ & & \\
\hline \multirow{3}{*}{ B } & 1 & 2 & $50.15 \pm 1.45$ & \multirow{3}{*}{0.757} & \multirow{3}{*}{0.504} \\
\hline & 2 & 4 & $155.06 \pm 67.77$ & & \\
\hline & 3 & 4 & $224.15 \pm 105.23$ & & \\
\hline \multirow{2}{*}{$\begin{array}{c}\text { Leaf Sample } \\
\text { Group }\end{array}$} & \multirow{2}{*}{$\begin{array}{l}\text { Level of } \\
\text { Pollution }\end{array}$} & \multirow[t]{2}{*}{$\mathrm{N}$} & Peroxidase Concentration ( $\mu \mathrm{g} / \mathrm{gm}$ F.W.) & \multirow[t]{2}{*}{$\mathrm{F}$} & \multirow[t]{2}{*}{ p-value } \\
\hline & & & Mean \pm S.E. & & \\
\hline \multirow[t]{2}{*}{$\mathrm{T}$} & 1 & 6 & $173.92 \pm 58.22$ & \multirow{2}{*}{13.548} & \multirow{2}{*}{$0.005 *$} \\
\hline & 2 & 5 & $452.01 \pm 43.84$ & & \\
\hline \multirow[t]{2}{*}{ A } & 1 & 6 & $209.38 \pm 53.64$ & \multirow{2}{*}{8.879} & \multirow{2}{*}{$0.015 *$} \\
\hline & 2 & 5 & $522.97 \pm 96.32$ & & \\
\hline \multirow[t]{2}{*}{ B } & 1 & 6 & $71.99 \pm 15.24$ & \multirow{2}{*}{8.951} & \multirow{2}{*}{$0.017 *$} \\
\hline & 2 & 4 & $296.29 \pm 91.72$ & & \\
\hline
\end{tabular}

* Significant difference at $\mathrm{p}=0.05$

Table 5. Paired t-test for comparing means of peroxidase level of leaf groups $\mathrm{T}$ and $\mathrm{A}$ of $A$. philoxeroides within pollution categories.

\begin{tabular}{|c|c|c|c|c|c|}
\hline \multirow{2}{*}{ Level of Pollution } & \multirow{2}{*}{$\mathrm{N}$} & \multicolumn{2}{|c|}{ Correlation } & \multirow{2}{*}{$\mathrm{df}$} & \multirow{2}{*}{ Significance (paired) (2-tailed } \\
\hline & & $\mathrm{r}$ & Sig & & \\
\hline Low & 6 & 0.803 & 0.054 & 5 & 0.362 \\
\hline High & 5 & 0.234 & 0.705 & 4 & 0.500 \\
\hline
\end{tabular}

dense-strands and the specific clonal network might be a factor facilitating their expansion in diverse habitats (Wang et al. 2009; Xu et al. 2010). Physiological integration facilitates coordinated growth (Holzapfel and Alpert 2003), ability to exchange substances via vascular transport of resources (Pitelka and Ashmun 1985), increases cooperation (de Kroon and Groenendael 1997) and is a major ecological advantage of clonal plants ( $\mathrm{Du}$ et al. 2010). We, therefore, hypothesize in this case, that high levels of infestation would not create any intraspecific stress among the plants (due to competition), reflected through peroxidase levels, possibly because of their clonal vegetative growth, which allows them to spread without any hindrance.

From Table 4, it was evident that there were no significant differences in mean peroxidase concentration $(\mu \mathrm{g} / \mathrm{gm} \mathrm{F} . \mathrm{W}$.) for each of the three leaf groups across ponds graded into High, Medium and Low, on the basis of "A. philoxeroides infestation" thereby confirming our hypothesis that strand-density did not have any stress-related effect on A. philoxeroides. On the contrary, this might indicate that increased strand-density could be a beneficial factor for the survivality and propagation of $A$. philoxeroides in aquatic habitats. The ability of the plant to propagate vegetatively is probably instrumental for its spread and its high rate of growth may be one reason for its high degree of colonization (Zuo et al. 2012). Positive density dependent growth was also reported by Cain et al. (1995) in the clonal plant Trifolium repens.

\section{Stress due to "Level of Pollution"}

Peroxidase activity in plant tissues has been suggested as an indicator of environmental pollution stress in both air (Keller 1974, Varshney and Varshney 1985) and water (Roy et al. 1992, Nimptscha et al. 2005). Specifically in aquatic systems, increase in peroxidase activity has been used as a biochemical indicator of increased organic (Santra et al. 2003) and toxic chemical (Byl et al. 1994) pollution. In view of the above, an attempt was made to correlate levels of peroxidase with differences in the High and Low pollution grades of the study ponds. 
Significant difference in the mean peroxidase concentration of $A$. philoxeroides was found in the pond groups (High and Low) categorized on the basis of "Level of Pollution", with respect to all the three leaf group samples $\mathrm{T}(\mathrm{p}=0.005)$, A $(p=0.015)$ and $B(p=0.017)($ Table -4$)$. It can be seen from Table -2 that a general trend of higher peroxidase values $(>300 \mu \mathrm{g} / \mathrm{gm} \mathrm{FW})$ in A. philoxeroides in groups (T) and (A) could be observed in case of ponds with higher influx of wastes (namely Pond 5, and 8 - 11), which might support the assumption that higher peroxidase concentration enhances the tolerance of A. philoxeroides to adapt to stress conditions. Zou et al (2012) also reported that aquatic A. philoxeroides showed higher amount of peroxidase, which provides a greater resistance to adverse conditions in aquatic ecosystems. Peroxidase activity in aquatic plants was considered to be a critical determinant of tolerance to water pollution caused by pulp and paper mill effluents (Roy et al. 1992), other industrial effluents (Nayek et al. 2010) and also to heavy metals (Naqvi and Rizvi 2000), like copper (Xu et al. 2011a), zinc (Yuan et al. 2009) and cadmium (Ding et al. 2007).

\section{Conclusion}

This study shows evidence in favour of two specific traits of Alternanthera philoxeroides that are reported to facilitate plant adaptations in different environments, namely, its ability to grow even under high strand density (through absence of stress due to infestation) and its ability to withstand a broad range of environmental conditions (through increase in peroxidase concentration in plants exposed to higher influx of pollution). The capacity of A. philoxeroides to grow and proliferate in different grades of pond ecosystems and its wide adaptability might be due to the high antioxidative protection provided by its stress enzymes. Further studies are needed to understand the mechanism of enhanced peroxidase levels under stress due to eutrophication. Collection of adequate amounts of leaf samples for enzyme assays by using the young leaves along with the fresh tips (leaf buds) makes the collection and extraction process much faster and more efficient thereby helping in better assessment of the ecological health and status of plant species.

Unfortunately, A. philoxeroides has not yet been granted any special invasive/pest species status at the governmental level in India, although it has been reported to be an invasive alien flora of India (Reddy et al. 2008). On the other hand, in view of its negative ecological impacts, this plant has already been identified and given a special "weed-status" in many other countries, for instance, in USA (http://www.plants. usda.gov), Tasmania (http://www.dpiw.tas.gov.au), New Zealand (http://www.waikatoregion.govt.nz) and Australia (http://www.dpi.nsw.gov.au). A. philoxeroides was added to the EPPO Alert List in 2007 and transferred to the List of Invasive Alien Plants in 2012 (http://www.eppo.nint) showing the increasing cause of concern for this species.

This study points to the presence of A. philoxeroides infestations of varying population sizes in pond ecosystems in Kolkata, India. Its ability to survive as a dominant flora in association with other plants also constitutes a serious threat to other native plants and organisms. The ability of the plant to occupy disturbed habitats, a trait of a successful invader (Cadotte et al. 2006), complemented with its ability to withstand stress reflected through its higher peroxidase levels indicates its capability to become a successful invader. This paper emphasizes the latent risk of rapid invasion of A. philoxeroides in aquatic ecosystems and wetlands and highlights the urgency for creating awareness, both at the public and governmental level, about its potential risk of spread and thereby initiation of proper management procedures before expensive control measures become imperative.

\section{Acknowledgements}

We would like to thank Mr. Lachman B. Magranti, Mr. Sandip Chatterjee and Mr. Susant Mahankur, of AERU, ISI, for their help in the field sampling of the plants and Professor Anup Dewanji, of ASU, ISI, for his help during the statistical analysis of the data. We would also like to thank the reviewers for their valuable suggestions for the improvement of the manuscript.

\section{References}

Aki C, Güneysu E, Acar O (2009) Effect of industrial wastewater on total protein and the peroxidase activity in plants. African Journal of Biotechnology 8 (20): 5445-5448

APHA (1998) Standard methods for the examination of water and wastewater, 20th edn. American Public Health Association, Washington DC, $1220 \mathrm{pp}$

Balagtas-Burrow GE, Moroney JV, Longstreth DJ (1993) Growth and osmotic adjustment of cultured suspension cells from Alternanthera philoxeroides (Mart.) Griseb after an abrupt increase in salinity. Journal of Experimental Botany 44: 673679, http://dx.doi.org/10.1093/jxb/44.3.673 
Blank RR (2010) Intraspecific and interspecific pair-wise seedling competition between exotic annual grasses and native perennials: plant-soil relationship. Plant and Soil 326: 331343, http://dx.doi.org/10.1007/s11104-009-0012-3

Byl TD, Sutton HD, Klaine SJ (1994) Evaluation of peroxidase as a biochemical indicator of toxic chemical exposure in the aquatic plant Hydrilla verticillata, Royle. Environmental Toxicology and Chemistry 13: 509-515, http://dx.doi.org/ 10.1002/etc.5620130322

Cadotte MW, Murray BR, Lovett-Doust J (2006) Ecological patterns and biological invasions: using regional species inventories in macroecology. Biological Invasions 8: 809821, http://dx.doi.org/10.1007/s10530-005-3839-4

Cain ML, Spacala SW, Silander Jr JA, Fortin MJ (1995) Neighborhood Models Of Clonal Growth In The White Clover Trifolium repens. The American Naturalist 145: 888917, http://dx.doi.org/10.1086/285775

Cakmak I, Marschner H (1992) Magnesium Deficiency and High Light Intensity Enhance Activities of Superoxide Dismutase, Ascorbate Peroxidase, and Glutathione Reductase in Bean Leaves. Plant Physiology 98: 1222-1227

Cook CDK (1996) Aquatic and Wetland Plants of India, Oxford University Press, pp 41-42

Chatterjee A, Dewanji A (2010) Global Climate Change and Biotic Invasion: A Case Study of a Wetland Plant Species. In: Reddy MA, Lakshmi TV (eds), (2010) Proceedings of 2nd International Conference on Environmental Management. October 25-28, 2010. Jawaharlal Nehru Technological University, Hyderabad, India. B.S. Publications, pp 270-277

de Kroon H, van Groenendael J (1997) The ecology and evolution of clonal growth in plants. Backhuys Publishers, Leiden, 453 $\mathrm{pp}$

Ding B, Shi G, Xu Y, Hu J, Xu Q (2007) Physiological responses of Alternanthera philoxeroides (Mart.) Griseb leaves to cadmium stress. Environmental Pollution 147 (3): 800-803, http://dx.doi.org/10.1016/j.envpol.2006.10.016

Du J, Wang N, Alpert P, Yu MJ, Yu FH, Dong M (2010) Clonal integration increases performance of ramets of the fern Diplopterygium glaucum in an evergreen forest in southeastern China. Flora 205: 399-403

Fekete S, Mándy A, Stefanovits-Bányai E (2002) Change of peroxidase enzyme activities in annual cuttings during rooting. Acta Biologica Szegediensis 46(3-4): 29-31

Gao J, Xiao Q, Ding L, Chen M, Yin L, Li J, Zhou S, He G (2008) Differential responses of lipid peroxidation and antioxidants in Alternanthera philoxeroides and Oryza sativa subjected to drought stress. Plant Growth Regulations 56: 89-95, http://dx.doi.org/10.1007/s10725-008-9291-6

Geng YP, Pan XY, Xu CY, Zhang WJ, Li B, Chen JK, Lu BR, Song ZP (2007) Phenotypic plasticity rather than locally adapted ecotypes allows the invasive alligator weed to colonize a wide range of habitats. Biological Invasions 9: 245-256, http://dx.doi.org/10.1007/s10530-006-9029-1

Hanfeng X, Qiling T, Chengxiao H (2010) Structural and metabolic responses of Ceratophyllum demersum to eutrophic conditions. African Journal of Biotechnology 9(35): 5722-5729

Holzapfel C, Alpert P (2003) Root cooperation in a clonal plant: connected strawberries segregate roots. Oecologia 134: 7277, http://dx.doi.org/10.1007/s00442-002-1062-x

Homans FR, Smith DJ (2011) Evaluating management options for aquatic invasive species: concepts and methods. Biological Invasions, http://dx.doi.org/10.1007/s10530-011-0134-4

Jain A, Roshnibala S, Kanjilal PB, Singh RS, Singh HB (2007) Aquatic/semi-aquatic plants used in herbal remedies in the wetlands of Manipur, Northeast India. Indian Journal of Traditional Knowledge 6(2): 346-351
Jaleel CA, Gopi R, Manivannan P, Gomathinayagam M, Sridharan R, Panneerselvam R (2008) Antioxidant potential and indole alkaloid profile variations with water deficits along different parts of two varieties of Catharanthus roseus. Colloids and Surfaces B: Biointerfaces 62(2): 312-318, http://dx.doi.org/10.1016/j.colsurfb.2007.10.013

Jia X, Pan XY, Li B, Chen JK, Yang XZ (2009) Allometric growth, disturbance regime, and dilemmas of controlling invasive plants: a model analysis. Biological Invasions 11(3): 743-752, http://dx.doi.org/10.1007/s10530-008-9288-0

Julien MH, Skarratt B, Maywald GF (1995) Potential Geographical distribution of alligator weed and its biological control by Agasicles hygrophila. Journal of Aquatic Plant Management 33: 55-60

Keller T (1974) The use of peroxidase activity for monitoring and mapping air pollution areas. European Journal of Plant Pathology 4: 11-19

Mack RN, Simberloff D, Lonsdale WM, Evans H, Clout M, Bazzaz FA (2000) Biotic invasions: causes, epidemiology, global consequences, and control. Ecological Application 10: 689-710, http://dx.doi.org/10.1038/2061270a0

Maddox DM (1968) Bionomics of an alligator weed flea beetle, Agasicles sp. in Argentina. Annals of the Entomological Society of America 61: 1300-1305

Maheshwari JK (1965) Alligator Weed in Indian Lakes. Nature 206 (4990): 1270

Malik CP, Singh MB (1980) Plant Enzymology and HistoEnzymology - A Text Manual. Kalyani Publishers, India, pp $30-54$

Mangla S, Sheley RL, James JJ, Radosevich SR (2011) Intra and interspecific competition among invasive and native species during early stages of plant growth. Plant Ecology 212: 531542, http://dx.doi.org/10.1007/s11258-011-9909-z

Markkola AM, Ohtonen R, Tarvainen O (1990) Peroxidase activity as an indicator of pollution stress in the fine roots of Pinus sylvestris. Water Air and Soil Pollution 52(1): 149156, http://dx.doi.org/10.1007/BF00283120

Masoodi A, Khan FA (2012) Invasion of alligator weed (Alternanthera philoxeroides) in Wular Lake, Kashmir, India Aquatic Invasions 7: 143-146, http://dx.doi.org/10.3391/ ai.2012.7.1.016

Mukhopadhyay G, Dewanji A (2004) The ability of aquatic macrophytes to maintain water clarity in two tropical ponds. International Journal of Environmental Studies 61(5): 579586, http://dx.doi.org/10.1080/0020723042000212618

Naqvi SM, Rizvi SA (2000) Accumulation of chromium and copper in three different soils and bioaccumulation in an aquatic plant, Alternanthera philoxeroides. Bulletin of Environmental Toxicology 65: 55-61, http://dx.doi.org/10. 1007/s001280000094

Nayek S, Gupta S, Saha R (2010) Effects of metal stress on biochemical response of some aquatic macrophytes growing along an industrial waste discharge channel. Journal of Plant Interactions 5(2): 91-99, http://dx.doi.org/10.1080/1742914 0903282904

Negi PS, Hajra PK (2007) Alien flora of Doon Valley, Northwest Himalaya. Current Science 92(7): 968-978

Nimptscha J, Wunderlinb DA, Dollana A, Pflugmachera S (2005) Antioxidant and biotransformation enzymes in Myriophyllum quitense as biomarkers of heavy metal exposure and eutrophication in Suquía River basin (Córdoba, Argentina) Chemosphere 61(2): 147-157, http://dx.doi.org/10.1016/j. chemosphere.2005.02.079

Pan X, Geng Y, Zhang W, Li B, Chen J (2006) The influence of abiotic stress and phenotypic plasticity on the distribution of invasive Alternanthera philoxeroides along a riparian zone. Acta Oecologica 30: 333-341, http://dx.doi.org/10.1016/j. actao.2006.03.003 
Paria N, Mukherjee A (1981) Allelopathic potential of a weed, Alternanthera philoxeroides (Mart.) Griseb. Bangladesh Journal of Botany 10(1): 86-89

Pitelka LF, Ashmun JW (1985) Physiology and integration of ramets in clonal plants. In: Jackson JBC (eds), Population Biology and Evolution of Clonal Organisms. Yale University Press, New Haven, pp 399-435

Prasad SN, Jaggi AK, Tiwari AK, Kaushik P, Vijayan L, Murlidharan S, Vijayan VS (2004) Inland Wetlands of India Conservation Atlas. Salim Ali Centre for Ornithology and Natural History, Coimbatore, India, $222 \mathrm{pp}$

Quesada MA, Sanchez-Roldan C, Heredia A, Valpuesta V, Bukovac MJ (1992) Peroxidase and IAA-oxidase activities and peroxidase isoenzymes in the pericarp of seeded and seedless 'Redhaven' peach fruit. Plant Growth Regulations 11: 1-6, http://dx.doi.org/10.1007/BF00193836

Reddy CS, Raju VS (2005) Invasion of alligator weed (Alternanthera philoxeroides) in Andaman Islands. Journal of Bombay Natural History Society 102(1): 133

Reddy CS, Bagyanarayana G, Reddy KN, Raju VS (2008) Invasive Alien Flora of India. National Biological Information Infrastructure, USGS, USA, pp 2-34

Rout NP, Shaw BP (2001) Salt tolerance in aquatic macrophytes: possible involvement of the antioxidative enzymes. Plant Science 160(3): 415-423, http://dx.doi.org/10.1016/S01689452(00)00406-4

Roy S, Ihantola R, Hanninen O (1992) Peroxidase activity in lake macrophytes and its relation to pollution tolerance. Environmental and Experimental Botany 32 (4): 457-464, http://dx.doi.org/10.1016/0098-8472(92)90058-A

Sainty G, McCorkelle G, Julien M (1997) Control and spread of Alligator Weed Alternanthera philoxeroides (Mart.) Griseb., in Australia: lessons for other regions. Wetlands Ecology and Management 5(3):195-201, http://dx.doi.org/10.1023/A:100 8248921849

Santra SC, Debnath M, Samal AC, Das S (2003) Biomonitoring of water quality by peroxidase assay in macrophytes. Science and Culture 69 (1): 81-82

Schindler DW (1987) Detecting ecosystem responses to anthropogenic stress. Canadian Journal of Fisheries and Aquatic Sciences 44 (Suppl. 1): 6-25, http://dx.doi.org/10.11 39/f87-276

Shannon LM, Key E, Lew JY (1966) Peroxidase isozymes from Horseraddish root. I. Isolation and physical properties. Journal of Biological Chemistry 249(9): 2166-2172

Singh V, Pandey RP (1998) Alternanthera philoxeroides (Mart.) Griseb.: A new distributional record for Rajasthan. $J$. Economic and Taxonomic Botany 22(1): 225-226

Singh KK, Sharma BM, Usha K (2010) Biomass dynamics of the macrophytic species of Kharungpat lake, Manipur, India. The Bioscan 2: 373-382
Spencer NR, Coulson JR (1976) The Biological Control of Alligatorweed Alternanthera philoxeroides in the USA. Aquatic Botany 2: 177-190, http://dx.doi.org/10.1016/03043770(76)90019-X

Sprecher SL, Stewart AB, Brazil JM (1993) Peroxidase changes as indicators of herbicide induced stress in aquatic plants. Journal of Aquatic Plant Management 31: 45-50

Tao Y, Chen F, Wan K, Li X, Li J (2009) The Structural Adaptation of Aerial Parts of Invasive Alternanthera philoxeroides to Water Regime. Journal of Plant Biology 52(5): 403-410, http://dx.doi.org/10.1007/s12374-009-9051-9

Verma S, Dubey RS (2003) Lead toxicity induces lipid peroxidation and alters the activities of antioxidant enzymes in growing rice plants. Plant Science 164: 645-655, http://dx.doi.org/10.1016/S0168-9452(03)00022-0

Varshney SRK, Varshney CK (1985) Response of peroxidase to low levels of $\mathrm{SO}_{2}$. Environmental and Experimental Botany 25: 107-114, http://dx.doi.org/10.1016/0098-8472(85)90016-4

Wagh G K, Ghate HV, Ghate VS (1995) First record of the Alligator weed, Alternanthera philoxeroides (Mart.) Griseb. from Pune, Maharashtra. Journal of Bombay Natural History Society 92: 141-143

Wang N, Yu FH, Li PX, He WM, Liu J, Yu GL, Song YB, Dong $M$ (2009) Clonal integration supports the expansion from terrestrial to aquatic environments of the amphibious stoloniferous herb Alternanthera philoxeroides. Plant Biology (Stuttg) 11: 483-489, http://dx.doi.org/10.1111/j.14 38-8677.2008.00133.x

Xu X, Shi G, Ding C, Xu Y, Zhao J, Yang H, Pan Q (2011a) Regulation of Exogenous Spermidine on the reactive oxygen species level and polyamine metabolism in Alternanthera philoxeroides (Mart.) Griseb under Copper Stress. Plant Growth Regulations 63: 251-258, http://dx.doi.org/10.1007/s 10725-010-9522-5

Xu X, Shi G, Wang J, Zhang L, Kang Y (2011b) Copper-induced oxidative stress in Alternanthera philoxeroides callus. Plant Cell, Tissue and Organ Culture 106: 243-251, http://dx.doi. org/10.1007/s11240-010-9914-2

Xu CY, Schooler SS, Van Klinken RD (2010) Effects of clonal integration and light availability on the growth and physiology of two invasive herbs. Journal of Ecology 98: 833-844, http://dx.doi.org/10.1111/j.1365-2745.2010.01668.x

Yuan QH, Shi GX, Zhao J, Zhang H, Xu QS (2009) Physiological and proteomic analyses of Alternanthera philoxeroides under zinc stress. Russian Journal of Plant Physiology 56(4): 495502, http://dx.doi.org/10.1134/S1021443709040086

Zuo S, Ma Y, Shinobu I (2012) Differences in ecological and allelopathic traits among Alternanthera philoxeroides populations. Weed Biology and Management 12: 123-130, http://dx.doi.org/10.1111/j.1445-6664.2012.00443.x 